\title{
Impact of Corporate Governance on Value Creation and Corporate Productivity: Evidence from Tunisian Context
}

\author{
Rim Ayari ${ }^{1} \&$ Boutheina Regaieg ${ }^{2}$ \\ ${ }^{1}$ Faculty of Economics and Management of Tunis, University of Tunis El Manar, Tunis, Tunisia \\ ${ }^{2}$ Faculty of Law, Economics and Management of Jendouba, University of Jendouba, Tunisia \\ Correspondence: Rim Ayari, Faculty of Economics and Management of Tunis, University of Tunis El Manar, \\ Tunisia. E-mail: rimayari84@yahoo.fr
}

Received: November 24, 2017

Accepted: February 24, 2017

Online Published: February 28, 2018

doi:10.5539/ijef.v10n3p215

URL: https://doi.org/10.5539/ijef.v10n3p215

\begin{abstract}
The governance practices and the value of the company have ancient origins but still relevant. Faced with economic, social and environmental upheavals, the Tunisian company is subject to contradictory injunctions and must redefine its role in society. Today there is a general consensus that governance has a significant impact on the value of the company. The areas on which governance can act to create value are many and varied and there can be no question of looking at them exhaustively. The purpose of this paper is to examine the impact of governance mechanisms on the value creation of Tunisian firms, particularly measured by total factor productivity. Based on a sample of 28 corporations listed on Tunisian stock market during the period 2008-2014, our study employs regression analysis to test the impact of governance mechanisms on firm value as measured by productivity. As predicted by the theory, empirical data show (i) that debts have a negative and significant effect on productivity such as measured by the ratio of total debt to total assets. (ii) the presence of institutional investors on boards of directors also increases the value of the company. (iii) However, contrary to previous studies, the duality that combines the functions of the Chairman of the Board and the Chief Executive Officer has no effect on the value creation of Tunisian companies.
\end{abstract}

Keywords: corporate governance, ownership structure, board of directors, value creation, debt, productivity

\section{Introduction}

The development of the theory relating to corporate governance came therefore distinguish several means used to control officers to be able to reduce these conflicts. These control mechanisms are distinguished external control mechanisms such as the market for goods and services, labor market and the market for takeovers and internal control mechanisms which the most important is the expanded board by Fama and Jensen (1983). The company's system of government is treated as a set of internal mechanisms (board of directors and compensation system) and external (capital geography) or control (capital of geography and board) and an incentive mechanism through the role assigned to the compensation, whereby the investor makes sure to have a fair return on its investment. Corporate governance indicates a set of relationships between a company's management, its board, its shareholders and other stakeholders. The ownership structure and composition of the Board are considered as key elements of corporate governance. Previous studies have shown that corporate governance is related to the process of value creation. On measures of value creation companies, some researchers have become interested at the productivity of a company and employees of the total factor productivity (TFP) as a measure of the value of a company. (Schoar, 2002; Barth et al., 2005).

Most research that studies the relation between corporate governance and value creation is based on the three theoretical paradigms analyzed by Nicholson and Kiel (2007): (i) agency theory, under which the role of the board as supervisor, and the control he exercises, are established; (ii) the stewardship theory, according to which the board of directors assumes an advisory role vis-à-vis the management team; and, lastly, (iii) the theory of resource dependence, in which the council acts as a link between the organization and its environment, and facilitates the capture of resources (Pucheta-Martínez, 2015). Many of the previous studies of the relationship between consulting and value creation in the business have been based solely on agency theory. However, the inclusion of the council's advisory role in the analysis has led recent researchers to keep the stewardship perspective in mind and to emphasize its importance, especially in turbulent contexts (Pucheta-Martínez, 2015).

This study intended to investigate the relationship between corporate governance and the total factor productivity 
of Tunisian industrial companies. We also study the question about the efficiency of corporate governance in the conglomerate companies over non conglomerate, family companies compared to non-family and finally the high technology companies versus non-high technology companies. Conglomerate corporate, in general, have a lower value productivity than non-conglomerate companies and bad results when investing in different segments of activities due to imperfections or in corporate governance (problem of agency) or on financial markets (incorrect valuations of the segments of the business industry) (Claassen et al., 2000; Kao et al., 2004).

The literature on the effect of corporate governance and corporate productivity has grown in recent years. While some studies (Bhagat \& Bolton, 2008; Yang \& Zhao, 2014) indicate that there is a direct relationship between these two variables, several studies show the indirect effect of corporate governance on the productivity.

For example, Mcdonald et al. (2008) find that the external CEO network influences the effect of CEO share ownership on firm productivity for a sample of US firms. Zhang et al. (2014) find that investment in research and development $(\mathrm{R} \& \mathrm{D})$ influences the relationship between the concentration of ownership and the value of the firm for a sample of Chinese IT firms.Moreover, the performance of family companies may be less effective than non-family companies.

The concentration of ownership in family firms involves limited diversification of financial risks and a higher cost of capital to the risk premium (Demestez \& Lehn, 1985). In addition; we also examine the governance structure in the high-tech companies and not high technology. High-tech companies generally invest in R\&D and therefore generate higher productivity than non-high technology firms (Wang \& Tsai, 2003). The corporate governance structure in high technology companies may be either an improvement or aggravating factors in productivity. Therefore, it is important to examine whether the corporate governance structure influences the productivity of high-tech and non- high-tech companies.

Our study aims to find a significant relationship between corporate governance mechanisms and value creation through productivity as found by several empirical works such as Schoar (2002), Barth et al. (2005). These authors emphasize the importance of governance mechanisms in increasing value creation.

The remaining part of this article is organized as follows. Section 2 establishes the links between corporate governance and TFP. The research design is described in section 3. Section 4 reports the empirical results, followed by our conclusions in section 5 .

\section{Institutional Setting and Development of Hypotheses}

\subsection{The Impact of Ownership Structure on Productivity}

\subsubsection{Insiders Ownership}

Productivity is improved efficiency in the economic performance of a company after taking into account the contribution of input costs. It has long been recognized in economics that total factor productivity is an important element of economic growth at the firm level. However, is that the productivity of firms is related to the value of businesses? Lichtenberg and Palia (1999) found a positive correlation between total factor productivity and value of the company (measured by Tobin's Q). While good internal governance has been found to improve the company's value. Most of the previous studies (Campbell \& Vera, 2010; Mínguez-Vera \& López Martinez, 2010; Vivel et al., 2015) have obtained a negative and significant correlation between corporate governance and the Tobin $\mathrm{Q}$ ratio. We expect the same relationship because, like these authors, we consider that small firms have higher productivity. Finally, we expect that companies with better ROAs will also have a higher enterprise value, as shown by the results obtained by Campbell and Vera (2010) and Vivel et al. (2015). Is financial leverage a mediating variable between corporate governance and corporate performance? To our knowledge, this issue has not been addressed in the literature. The existing literature focuses primarily on (1) the effect of corporate governance on corporate value (Chen et al., 2014), and (2) the effect of leverage on productivity (González, 2013, Vithessonthi \& Tongurai, 2015).

So it remains to consider the impact of internal and external governance on company productivity. Researchers in economics, management and finance have long analyzed the importance of the ownership structure. For example, Sliver and Vishny (1986) argue that blocks holders have the ability and the incentive to follow the business leaders and reduce agency costs and improve corporate value. Morck et al (1988) and McConnell and

Servaes (1990), among others who identify a curvilinear relationship between Tobin's Q and the proportion of shares held by insiders of the property. Agrawal and Knoeber (1996) and Ho (2005) find that the ownership of insiders is positively related to the value creation of the company.

Hypothesis 1: The Insiders Ownership is positively related to TFP 


\subsubsection{Institutional Ownership}

Ownership structure is also based on the existence of institutional investors who hold the highest fraction quoted on financial markets namely insurance companies, banks securities, collective Organizations Investment in Transferable Securities, pension Funds. Hawkins (1999) found evidence consistent with the hypothesis that control of companies by institutional investors may lead managers to focusing more on business performance and less on opportunistic or selfish behavior. Several studies conclude that the goal of institutional investors to maintain the liquidity of their assets and their short-term profit will exceed the benefits to control the management in the hope and generate higher long-term profitability (see Bhide, 1994; Demirag, 1998). Similarly, Hudson, Parrino and Starks (1998) found that institutional investors are critical bearings in the discipline of executives. Other empirical evidence is consistent with the importance of controlling played by institutional investors. However, it is noted that Denis and Sarin (1997) found that the rotation of senior management is not related to the shareholding of institutional investors.

Hypothesis 2: the presence of institutional investors in the ownership structure is positively related to TFP

\subsection{The Impact of Board of Directors Characteristics on Productivity}

The company's value can be affected by various characteristics of the board. In this way, many studies find that the value of companies is negatively related to the size of the board while others present contradictory evidence. For example, Jensen (1993) argues that a smaller council, be able to exercise more effective control, should have a positive impact on the company's value.

\subsubsection{Board Size}

The empirical results of Pucheta-Martínez (2015) have opened a new path. The number of board members improves performance, but only to a limited extent. Similar evidence has been revealed by Hillman et al. (2011) and Cabrera-Suárez et al (2015) who argued that a balance should be drawn between the benefits (supervision and advice) and the disadvantages (coordination, control and decision-making issues) of a large board. Yermack (1996) and Conyon and Peck (1998) find that firms with tips of small sizes have a high Tobin Q. Eisenberg et al (1998) demonstrated that the boards of small sizes are associated with better performance which leads to a company's value creation. Yermack (1996) suggests that a large board increases the problems of communication and coordination and then decreases the capacity of the board to the control of management. So this leads to agency problems arising from the separation between management and control. Brown and Caylor (2004) adds to this literature by showing that board sized companies between 6 and 15 have higher returns on equity and higher profit margins than do not companies with boards of another size.

Hypothesis 3: the small board is positively related to TFP

\subsubsection{CEO Duality}

The theory of agency costs by Jensen and Meckling proposed (1976) suggests that the agency problem is increasing and therefore the company's performance decreases as the CEO concurrently serves as Chairman of the Board (CEO duality). This is due to a fact that is the duality of the CEO that the Director General responsible for making and implementing strategic decisions also assesses the effectiveness of these decisions. Therefore, the duality of CEO increases the possibility that the latter is acting in its own interest. This leads to the advantage taken, the ineffective behavior of a CEO and the decrease in value of the company and therefore the decrease in productivity. Furthermore, the organization theory suggests that the control unit of a general manager led to a clear leadership, therefore, induced to effective decision making (Donaldson \& Davis, 1991).

This creates better productivity. Several empirical studies (Pi \& Timme, 1993; Baliga et al., 1996) have provided evidence showing that companies with separation of the positions of CEO and chairman obtain better results than companies with the combination of these.

Hypothesis 4: The concentration of power (CEO Duality) negatively affects TFP.

\subsection{The Impact of Debt Policy on Productivity}

Jensen (1986) suggests that debt is an important mechanism to control opportunistic behavior of leaders. The debt limits the discretion of the leaders in reducing the amount of free cash flow, which is likely to limit unprofitable investments such as acquisitions of companies often overpaid. The discipline imposed by debt means that managers will use the resources of the company efficiently on projects that are likely to create value for shareholders. A lot of research was then conducted demonstrating that the debt can influence the leaders by threatening their jobs, their reputation and their benefits (Grossman \& Hart, 1982). Debt can also improve company's productivity or its growth (Nickell et al., 1997), confirming its power.The debt is used to give 
credibility the choice of leaders by pledging not to choose profitable investments (Zwiebel, 1996).

In the Spanish case, the code of good governance (2015) states that the duality between the CEO and the chairman of the board of directors has both advantages and disadvantages. The main benefits in reducing information and coordination costs in clear leadership. On the other hand, the main drawback is the concentration of power in a person. However, it is inappropriate for these codes; the Code makes no recommendation on the separation of the two roles, but rather the same lines as the previous job codes (Unified Code, 2006; updated in 2013). The theory of stewardship supports the idea that dual CEOs contribute to timely decision-making, effective execution of plans and effective monitoring, leading the company to better performance (García-Ramos \& García-Olalla, 2014). Consistent with the above, other studies have found a positive relationship between CEO duality and performance in low-munificence and high-complexity environments (Chen, 2014; Chang et al., 2015).

Hypothesis 5: The high debt ratio negatively affects TFP.

\section{Research Design}

A view to empirically test the effect of governance mechanisms on corporate value creation and in particular the total factor productivity, we proceeded to the selection of a sample composed of listed Tunisian firms. The choice of this sample to the limited number, 28 companies, and observations are made over a period of 7 years, spanning from 2008 to 2014. The data is collected from the stock exchange in Tunis (Tunis Stock Exchange). The choice of variables in our database is performed according to recent studies on the productivity of industrial companies

\subsection{Variables of the Study}

-

Dependent Variable

Productivity: the endogenous variable of our model as measured by total factor productivity. The higher this factor, the greater the productivity of the company is high and so it has an incentive to create value.The total factor productivity (TFP of a company is defined by a unit of input required to produce a given quantity of output where total inputs is a weighted sum of the individual inputs that is saying: $\mathrm{TFP}=\mathrm{Y}_{\mathrm{it}} / \mathrm{F}\left(\mathrm{L}_{\mathrm{it}}, \mathrm{k}_{\mathrm{it}}\right)$

with: $\mathrm{Y}$ : outputs, $\mathrm{F}\left(\mathrm{L}_{\mathrm{it}}, \mathrm{k}_{\mathrm{it}}\right)=\mathrm{k} \alpha$. $\mathrm{L}$ represents the Cobb-Douglas production function L: labor input, $\mathrm{K}$ : capital factor, $\alpha$ and respectively represents the elasticity of output with respect to capital input and labor input.

We adopt net sales as the measure of each company outputs. According Schoar (2002), the sum of direct and indirect costs of work is used for the measurement of labor and the real net stock as a measure of capital input.

- Independent variables

OS1: this variable is measured by the percentage of shares held by insiders of the property, that is to say, officer and shareholder holding more than 10 percent of total company shares.

OS2: this variable is determined by the percentage of shares held by institutional investors.

Board size: this variable represents the size of the board. It is measured by the natural logarithm of the number of directors serving on the board.

Management: this variable represents the duality. This is a dummy variable taking the value 1 when the positions of CEO and chairman are held by the same person and the value 0 otherwise.

Collateral: it is a variable of guarantee. It is measured by the percentage of guaranteed shares held by the board of directors.

Table 1. Explanatory and control variables definition

\begin{tabular}{|c|c|c|c|}
\hline Variable & Code & Measurement & Authors \\
\hline \multicolumn{4}{|c|}{ Panel A: Explanatory variables measurement } \\
\hline $\begin{array}{l}\text { Insiders } \\
\text { Ownership }\end{array}$ & OS1 & $\begin{array}{l}\text { Measured by the percentage of shares held by insiders } \\
\text { of the property, that is to say, officer and shareholder } \\
\text { holding more than } 10 \text { percent of total company shares. }\end{array}$ & $\begin{array}{l}\text { Morck et al. (1988); McConnell \& } \\
\text { Servaes (1990); Agrawal \& Knoeber } \\
\text { (1996); Ho (2005) }\end{array}$ \\
\hline $\begin{array}{l}\text { Institutional } \\
\text { Ownership }\end{array}$ & OS2 & $\begin{array}{l}\text { Measured by the percentage of shares held by } \\
\text { institutional investors }\end{array}$ & $\begin{array}{l}\text { Bhide, 1994; Denis \& Sarin (1997); } \\
\text { Demirag (1998); Hawkins (1999) }\end{array}$ \\
\hline Board Size & BOARD_SIZE & $\begin{array}{l}\text { Measured by the natural logarithm of the number of } \\
\text { directors serving on the board. }\end{array}$ & $\begin{array}{l}\text { Yermack (1996); Conyon \& Peck (1998); } \\
\text { Hillman et al. (2011); Pucheta-Martínez } \\
\text { (2015); Cabrera-Suárez et al. (2015) }\end{array}$ \\
\hline
\end{tabular}




\begin{tabular}{|c|c|c|c|}
\hline CEO Duality & MANAGEMENT & $\begin{array}{l}\text { Dummy variable taking the value } 1 \text { when the positions } \\
\text { of CEO and chairman are held by the same person and } \\
\text { the value } 0 \text { otherwise. }\end{array}$ & $\begin{array}{l}\text { Donaldson \& Davis (1991); Pi \& Timme } \\
\text { (1993); Baliga et al. (1996) }\end{array}$ \\
\hline Collateral & COLLATERAL & $\begin{array}{l}\text { Measured by the percentage of guaranteed shares held } \\
\text { by the board of directors. }\end{array}$ & Porta et al. (1999); Kao et al. (2004) \\
\hline \multicolumn{4}{|c|}{ Panel B: Control variables measurement } \\
\hline $\begin{array}{l}\text { Investment } \\
\text { opportunities }\end{array}$ & R\&D & $\begin{array}{l}\text { Calculated by dividing the expenditures in } R \& D \text { by } \\
\text { total sales }\end{array}$ & Nash et Poulsen (2003) \\
\hline $\begin{array}{l}\text { market value of } \\
\text { the company }\end{array}$ & $\begin{array}{l}\text { MARKET } \\
\text { VALUE }\end{array}$ & $\begin{array}{l}\text { Measured by the market value of the outstanding } \\
\text { common shares of the company }\end{array}$ & Schoar (2002) \\
\hline Debt Policy & DEBT & Measured by total debt to total assets ratio & $\begin{array}{l}\text { Zwiebel (1996); Ghosh et al. (2010); } \\
\text { Abed et al. (2012) }\end{array}$ \\
\hline
\end{tabular}

Author (Own elaboration).

\subsection{Regression Model Specifications}

To verify our research hypotheses we apply a statistical methodology implementing a linear panel regression. The model in order to explain the correlations between the different variables used in relation to productivity firms. The model to be estimated is as follows:

$$
\begin{gathered}
\text { TFP }=a+a_{1 i, t} \text { OS }_{1}+a_{2 i, t} O_{2}+a_{3 i, t} \text { BOARD_SIZE }+a_{4 i, t} \text { COLLATERAL }+a_{5 i, t} M A N A G E M E N T+a_{6 i, t} R \& D+a_{7 i, t} \\
\text { MARKETVALUE }+a_{8 i, t} D E B T+\mu i+\varepsilon_{i, t}
\end{gathered}
$$

Where: TFP: total factor productivity as measured by estimating the logarithm of the Cobb- Douglas production function: TFP $=\ln \mathrm{Y}$ it $-\alpha \ln \mathrm{Lit}-\beta \ln \mathrm{Kit},[\mathrm{i}=1 \ldots \ldots .5$ ]; $[\mathrm{t}=2008 \ldots \ldots$. 2014]; [a: Settings to estimate.], OS1: insider's ownerships measured by the percentage of shares held by insiders of the property; OS2: institutional investor participation is determined by the percentage of shares held by institutional investors. BOARD SIZE: the size of the board, measured by the natural logarithm of the number of directors serving on the board. COLLATERAL: variable of guarantee, measured by the percentage of guaranteed shares held by the board of directors. MANAGEMENT: CEO duality board members, measured by a dichotomous variable equal to 0 if the firm $i$ is separated between the role of CEO and Chairman, and 1 otherwise; R\&D: Research and development, calculated by dividing the expenditures in R\&D by total sales. MARKET VALUE: the market value of the company. It is used to control the company's size effect on productivity, measured by the market value of the outstanding common shares of the company. DEBT: Debt, measured by total debt to total assets ratio.

We now go to the presentation of different methods for estimating a panel model. Our estimation is performed in three models where the difference lies only in the classification of different companies: family company and non-family, high-tech company and non-high technologies and Conglomerate Company and non-conglomerate. The estimation of the three models will be made by the "STATA" software. To do this, we test the homogeneity of our sample, that is to say, to see if there are specific individual effects.

\section{Results}

4.1 Multivariate Analysis

\subsubsection{Testing Panel Data}

\begin{tabular}{|c|c|c|c|}
\hline & Tests & Hypotheses. & Results \\
\hline \multicolumn{4}{|c|}{ Panel A: linear regression between total factor productivity and ownership structure. } \\
\hline \multirow[t]{3}{*}{ specification test } & Fisher test & H0: no fixed effects & $F(27,79)=24.67$ Prob $>F=0.000$ \\
\hline & Hausman test & H0: presence of random effects. & Chi2 $=5.89$ \\
\hline & & & Prob $>$ chi2 $=0.05$ \\
\hline \multicolumn{4}{|c|}{ Panel B: quadratic regression between total factor productivity and ownership structure. } \\
\hline \multirow[t]{3}{*}{ specification test } & Fisher test & H0: no fixed effects & $F(27,79)=26.97$ Prob $>F=0.000$ \\
\hline & Hausman test & H0: presence of random effects. & Chi2 $=11.52$ \\
\hline & & & Prob $>$ chi2 $=0.05$ \\
\hline
\end{tabular}

Table 2. Model specification tests

Author (Own elaboration). 
Panel A presents the linear regression between total factor productivity and ownership structure. The application of the homogeneity test in this model allows us to conclude on the existence of the heterogeneity problem because $F(27,79)=24,87$ and Prob $>F=0,000$. As a result, the Ordinary Lesser Square (OLS) method will be biased. So, we estimate model 1 with fixed or random specific effects. Then we choose the model to remember (fixed or random). The Hausman test, which aims at choosing the model to retain, allowed us to choose the random effect model since $\mathrm{P}(\chi 2)=0.3167>0.05$.

Panel B presents a quadratic regression between total factor productivity and ownership structure. The application of the homogeneity test in this model allows us to conclude with respect to the existence of the heterogeneity problem because $F(27,79)=26.97$ and Prob $>F=0.000$. As a result, the Ordinary Lesser Square (OLS) method will be biased. So, we estimate the model 2 with specific fixed and random effects. Then we will choose the model to remember (fixed or random). The Hausman test, which aims at choosing the model to retain, allowed us to choose the random effect model since $\mathrm{P}(\chi 2)=0.0737>0.05$.

\subsubsection{Regression Results}

Estimates of the previous model using a pooled least squares (the analysis of our panel shows that there is a global homogeneity) are significant. This has encouraged us to use the common Effect method (Pooled Least).

Model 1 shows the linear regression between total factor productivity and the ownership structure. Model 2 shows quadratic regression between total factor productivity and the ownership structure. Model 3 shows the Quadratic Relationship between Total Productivity of Factors and the Different Factors of Corporate Governance.

Table 3. Estimated coefficients from corporate governance and productivity

\begin{tabular}{|c|c|c|c|c|c|c|}
\hline \multirow[b]{2}{*}{ Variables } & \multicolumn{2}{|c|}{ Model 1} & \multicolumn{2}{|c|}{ Model 2} & \multicolumn{2}{|c|}{ Model 3} \\
\hline & Coefficient & Probability & Coefficient & Probability & Coefficient & Probability \\
\hline constant & 1.339 & $2.75 *$ & 1.163 & $1.91 * * *$ & 0.887 & -0.96 \\
\hline OS1 & 0.002 & 0.35 & 0.012 & $2.35^{* *}$ & 0.015 & $2.68^{*}$ \\
\hline OS1 2 & & & -0.0001 & $-2.14 * *$ & -0.00013 & $-2.12 * *$ \\
\hline OS2 & 0.075 & $2.79 *$ & 0.132 & $1.98 * *$ & 0.116 & $2.14 * *$ \\
\hline BOARD_SIZE & & & & & -0.017 & $-2.67 *$ \\
\hline MANAGEMENT & & & & & 0.1399 & -0.42 \\
\hline $\mathrm{R} \& \mathrm{D}$ & 0.244 & $2.43 * *$ & 0.236 & $2.32 * *$ & 0.239 & $2.16^{* *}$ \\
\hline MARKET_VALUE & 0.0029 & -0.66 & 0.0029 & -0.66 & 0.0019 & -0.41 \\
\hline DEBT & -0.002 & -0.68 & -0.0023 & -0.76 & -0.011 & $-2.08 * *$ \\
\hline $\mathrm{R} 2 \%$ & \multicolumn{2}{|c|}{0.2101} & \multicolumn{2}{|c|}{0.1906} & \multicolumn{2}{|c|}{0.1985} \\
\hline $\mathrm{N}$ & \multicolumn{2}{|c|}{196} & \multicolumn{2}{|c|}{196} & \multicolumn{2}{|c|}{196} \\
\hline
\end{tabular}

Where: TFP: total factor Productivity; OS1: insider's ownerships measured by the percentage of shares held by insiders of the property; OS 2: institutional investor participation is determined by the percentage of shares held by institutional investors. BOARD_SIZE: the size of the board, measured by the natural logarithm of the number of directors serving on the board. COLLATERAL: variable of guarantee, measured by the percentage of guaranteed shares held by the board of directors. MANAGEMENT: CEO duality board members, measured by a dichotomous variable equal to 0 if the firm i is separated between the role of CEO and Chairman, and 1 otherwise; R\&D: Research and development, calculated by dividing the expenditures in R\&D by total sales. MARKET_VALUE: the market value of the company, measured by the market value of the outstanding common shares of the company. DEBT: Debt, measured by total debt to total assets ratio. $* / * * / * * *$ represent significance at the $10 / 5 / 1 \%$ level, respectively.

Author (Own elaboration).

Table 3 results of the linear relationship (model 1) and quadratic (model 2) between the total factor productivity and the ownership structure:

First, we analyzed the relationship between TFP and internal property. Note that the linear relationship in Model 1 between total factor productivity and ownership of insiders is not significant, which can be an indication of non-linearity.To test the significance of this apparent non-linearity, a quadratic term of the variable representing the ownership of insiders is introduced in Model 2. From the results, we find that the quadratic relationship between TFP and ownership of insiders is significant at the 5\% level. Therefore, the curvilinear relationship between the MFP and the internal property is identified, which is similar to the curvilinear relationship between the Q of Tobin and the property of internal found by Mc Connell and Servaes (1990) where the Tobin Q value initially increases until that the percentage of insider ownership reaches $38 \%$, then decreases if the property becomes concentrated in the hands of employees and managers. 
Secondly, we analyzed the relationship between total factor productivity and institutional ownership. It is found in Model 1 that the linear relationship between TFP and institutional ownership is significant at the $1 \%$ level while the quadratic relationship between these two variables is significant at the 5\% level in Model 2.

The model 3 shows the proportion of shares held by insiders on the one hand has a positive effect $(0.015)$ and significant at $1 \%$ on the total productivity of the other factors it has a negative effect (- 0.00013) and significant at 5\% threshold. This result corroborates the work of Morck et al (1988) that suggest that the value of businesses is adversely affected at levels of internal ownership between $5 \%$ and $25 \%$.In this interval, managers are rooted and may engage in activities that do not maximize the company's value. Moreover, in the internal property of levels exceeding $25 \%$, the relationship between the internal property and Q Tobin turns positive.

The analysis of the impact of debt known as a variable control of the financial leverage effect on business performance shows that this variable is significantly correlated to the 5\% threshold with the company's productivity with a negative $(-0.011)$, in other words, the higher the debt, the greater productivity is low which reduces the value of the business and so there is value destruction and inversely.So here, we can actually believe that a heavily indebted firm emerges poor performance which led to the fall bankruptcy. This result is consistent with that of Zwiebel (1996) which states that the debt is used to give credibility to the choices of leaders pledging to not choose unprofitable investments. The debt is therefore a means of discipline leaders since the increase in debt was accompanied by increased risk of bankruptcy. Thus a company concerned about creating value for its shareholders must reduce debt. In their study, Boutheina REGAIEG and Jamila FDHIL (2006) find that the bankruptcy risk calculation of a company depends on the quality of information disclosure, which means that every time a company is evaluated by the degree of clarity of information it will have a low risk of bankruptcy and eventually it will be rewarded with lower borrowing costs.

The estimated model thus reveals that duality has no effect on the company's productivity hence value creation. This result corroborates those of Baliga et al. (1996), Brickley et al. (1994), Dalton et al. (1998) which states that combining the functions has no effect on the company's value creation. The empirical results show that the size of the board has a negative impact (0.017) and statistically significant at $1 \%$ on the value creation of Tunisian companies. This result is consistent with the literature stating that the Board of Directors with a small number of administrators is more effective in the performance of his duties and in monitoring the executive council with a high number of members and the fact coordination problems (Hermalin \& Weisbach, 2003). So a small board allows better alignment of interests between managers and shareholders and therefore it generates increased business value. Our result is consistent with studies Yermack (1996), Eisenberg et al. (1998) and Faleye (2004) which reveal the existence of a negative correlation between the size of the board and corporate performance of their samples.

The presence of institutional investors has a positive effect (0.116) and significant at the 5\% threshold on value creation of Tunisian companies. In Tunisia, institutional investors are involved in the control and management of companies. Moreover, governments in Tunisia push these institutions, which are mostly public companies, to participate in the capital of certain companies and facilitate their financing, either by buying treasuries paper issued by these companies of which they are shareholders, or by the easy credit. Institutional investors can influence modes of organization by businesses benefit from their expertise in various fields. This could increase the value of the firm. This result confirms the work of Bathala et al. (1994) have shown that institutional interests are supposed to be able to mitigate the agency problem by providing more effective control. Moreover, Ho (2005) suggests that significant holdings of institutional investors raise the vigilance of the board, which in turn has a positive effect on firm value. Institutional investors therefore play an important role in reducing agency costs.

We report as well as spending on research and development have a positive effect $(0.239)$ and significant at the $5 \%$ threshold on the productivity of Tunisian companies which explains that companies that use more R\&D create more value. R\&D performed within a sector or a company has a direct impact on the productivity of the sector or the company in question by the fact that the results of research leads to technological innovations of products, production processes or organizational innovations that allow to produce more with the same amount of inputs. This relationship between R\&D and productivity growth has been empirically verified by numerous authors. Nadiri (1993), in summary of various studies suggests that the elasticity of output to R\&D is between about 10 and 30\% at company level and between 8 and 30\% at the industry. Mohnen and Mairesse (1999), in their most recent review of the literature on the effects of innovation on growth, are the elasticities of production to $R \& D$ (at company level) in the range of 5-30\%. 
Table 4. Estimated coefficients from the relationship between total factor productivity and the different factors of corporate governance in companies conglomerate against non-conglomerate, High Tech against non-High and family against non-family

\begin{tabular}{|c|c|c|c|c|c|c|c|c|c|c|c|c|}
\hline \multirow{3}{*}{ variables } & \multicolumn{4}{|c|}{ Panel 1 } & \multicolumn{4}{|c|}{ Panel 2} & \multicolumn{4}{|c|}{ Panel 3} \\
\hline & & & \multicolumn{2}{|c|}{ High technologie } & \multicolumn{2}{|c|}{ Non High tech } & \multicolumn{2}{|c|}{ Family } & \multicolumn{2}{|c|}{ Non family } \\
\hline & Coeff & Prob & Coeff & Prob & Coeff & Prob & Coeff & Prob & Coeff & Prob & Coeff & Prob \\
\hline constante & $-1,4885$ & $-0,91$ & 0,2485 & 0,2 & $-1,4557$ & $-1,1$ & 0,5291 & 0,33 & 0,9784 & 0,41 & 1,214 & 1,05 \\
\hline OS1 & 1,1359 & $3,01 *$ & 0,0574 & 1,15 & $-0,0223$ & $-1,23$ & 0,0721 & 1,59 & 0,0852 & $1,52 * * *$ & 0,0021 & 0,08 \\
\hline OS12 & $-0,0034$ & $-2,99 *$ & $-0,0005$ & $-1,42$ & 0,0006 & 0,22 & $-0,0006$ & $-1,50$ & $-0,0007$ & $-1,75^{* * *}$ & $-0,0001$ & $-0,31$ \\
\hline OS2 & 0,1544 & $2,95^{*}$ & 0,0159 & 0,95 & 0,0574 & $1,96 * *$ & 0,025 & 1,34 & 0,0546 & $-0,68$ & 0,0009 & 0,06 \\
\hline OS2*COLLATERAL & $-0,001$ & $-1,68^{*}$ & $-0,00008$ & $-0,48$ & $-0,00091$ & $-2,78^{* *}$ & $-0,00011$ & $-0,53$ & $-0,0002$ & $-0,30$ & $-0,00009$ & $-0,49$ \\
\hline BOARD SIZE & $-0,4454$ & $-3,00^{*}$ & $-0,04018$ & $-0,70$ & $-0,0695$ & $-0,81$ & $-0,1055$ & $-1,10$ & $-0,1579$ & $-1,65 * * *$ & $-0,1752$ & $-1,78^{* * * *}$ \\
\hline COLLATERAL & 0,0032 & 0,09 & 0,00006 & 0,01 & $-0,0608$ & $-3,04 *$ & $-0,0012$ & $-0,07$ & 0,0026 & 0,15 & 0,0042 & 0,27 \\
\hline MANAGEMENT & 1,2759 & $3,13^{*}$ & $-0,0259$ & $-0,06$ & 0,0885 & 0,35 & $-0,3689$ & $-0,47$ & $-0,2151$ & $-2,12^{* *}$ & $-0,0167$ & $-0,04$ \\
\hline$R \& D$ & 0,3366 & $1,62^{* * *}$ & 0,2987 & $1,73^{* * *}$ & 0,6811 & $1,73 * * *$ & 0,1776 & 0,61 & $-0,1264$ & $-0,57$ & 0,2446 & $1,92 * * *$ \\
\hline MARKET VALUE & $-0,0253$ & $-2,00 * *$ & 0,0018 & 0,33 & 0,2705 & 1,98 *** & 0,0087 & 0,60 & $-0,1264$ & $-1,30$ & 0,0019 & 0,39 \\
\hline DEBT & 0,0068 & 0,61 & $-0,0021$ & $-2,76^{*}$ & $-0,0109$ & $-2,72 *$ & $-0,0128$ & $-1,23^{* * * *}$ & $-0,004$ & $-0,36$ & 0,0002 & 0,06 \\
\hline R2 \% & \multicolumn{2}{|c|}{0,8256} & \multicolumn{2}{|c|}{0,0286} & \multicolumn{4}{|c|}{0,2933} & \multicolumn{2}{|c|}{0,844} & \multicolumn{2}{|c|}{0,2942} \\
\hline $\mathrm{N}$ & \multicolumn{4}{|c|}{196} & \multicolumn{4}{|c|}{196} & \multicolumn{4}{|c|}{196} \\
\hline
\end{tabular}

Where: TFP: total factor Productivity; OS1: insider's ownerships measured by the percentage of shares held by insiders of the property; OS2: institutional investor participation is determined by the percentage of shares held by institutional investors. BOARD SIZE: the size of the board, measured by the natural logarithm of the number of directors serving on the board. COLLATERAL: variable of guarantee, measured by the percentage of guaranteed shares held by the board of directors. MANAGEMENT: CEO duality board members, measured by a dichotomous variable equal to 0 if the firm i is separated between the role of CEO and Chairman, and 1 otherwise; R\&D: Research and development, calculated by dividing the expenditures in R\&D by total sales. MARKET VALUE: the market value of the company, measured by the market value of the outstanding common shares of the company. DEBT: Debt, measured by total debt to total assets ratio. $* / * * / * * *$ represent significance at the $10 / 5 / 1 \%$ level, respectively.

Author (Own elaboration).

Table 4 presents the from the relationship between total factor productivity and the different factors of corporate governance in companies conglomerate against non-conglomerate, High Tech against non-High and family against non-family. Panel 1 show that large institutional holdings are able to improve productivity in company's conglomerate. This result corroborates the work of Classens et al. (2000) show that the control mechanisms in the conglomerate companies in East Asia are relatively loose due to ineffective boards. The presence of institutional investors in boards of directors, however, can increase the capacity to monitor these (Shleifer \& Vishny, 1986; Bathala et al., 1994). Consequently, institutional holdings are more useful to create value in the business conglomerate that non conglomerate companies.In addition, the duality of CEO and R\&D spending has a positive and significant effect on productivity conglomerate companies. This indicated that the combined title of CEO and chairman ensures effective decision making leading to improved productivity of Tunisian conglomerate companies. This result support those Salancik and Pfeffer (1978) who suggested that the general director of duality allows for a single strong leader who is able to respond quickly to changes in the market environment. As against, R\&D expenditures have a positive (0.2987) and significant at the $10 \%$ level on productivity and debt has a negative impact (0.0021) and significant at the 5\% level of business productivity non conglomerates. This means that Tunisian companies with these activities are not diversified resorted to exploit more research and development that allow them to improve their products and to remain innovative in the market, but the increase in these funds increased debt those who thus a means of discipline leaders since the increase in debt was accompanied by the decrease of the value and increased bankruptcy risk.

In panel 2, we notes the presence of institutional investors on the board has a positive impact (0.0574) and significant at the $10 \%$ level on productivity in high-technology companies. In addition, R\&D spending positively affects (0.6811) and significantly at the $10 \%$ level of productivity in high-technology company. This means in these last, more spending on $\mathrm{R} \& \mathrm{D}$, the higher productivity is great. This invalidates the result of Hall and Oriani (2006) generally confirm that the positive contribution of investment in $R \& D$ to the performance of the company to high-technology and its valuation by the market. Thus the shares with a guaranteed in technology companies have a negative impact $(-0.0608)$ and significant at the $5 \%$ level this relationship was checked by Kao et al. (2004) who found that a share higher equity guaranteed by the board leads to the decrease of the company's value. Basically, collateral actions increase the deviation the cash flow rights from control rights held by the controlling shareholders. This induces a much more serious agency problem between controlling shareholders 
and external shareholders.

In panel 3, we note that a small board led to the improvement of productivity in family and non-family businesses. This result support the work of Yermack (1996), which suggests that a large board increases the problems of communication and coordination and then decreases the capacity of the board to the control of management. In addition, the proportion of shares held by insiders in the ownership of the family business has a positive and significant impact on productivity. This result supports those Demestez and Lehn (1985) which proves that the concentration of ownership in the hands of family members implies a limited diversification of financial risks and a high cost of capital due to the risk premium which improves productivity and increases the company's value. This situation may induce caution of family owners when new investments and reluctance to raise loans or admit new investors. So the introduction of new productivity-enhancing technologies is limited in family companies.

\section{Conclusion}

In this article, we tried to confront the reality of the Tunisian context explanatory theories of the impact of governance on the productivity of Tunisian industrial companies. To do this, we tried to determine the meaning of the relationships between specific variables of corporate governance with the total factor productivity from a sample of Tunisian companies composed of 28 companies listed on the BVMT a seven years period spanning from 2008 to 2014.To do this, we developed three models that relate productivity varies depending on variables related to the characteristics of the ownership structure including internal ownership and institutional ownership and other variables such as debt, the investment in R\&D activity, the market value of the company and the size of the board...The key findings emerged from this empirical study reveal that debts have a negative and significant effect on productivity. In addition, the duality has no effect on the productivity of Tunisian enterprises so on value creation and the presence of institutional investors has a positive and significant effect on the value of Tunisian companies.

This research presents a number of limitations that are also future avenues of research. First, the study is restricted by establishing only listed companies. Subsequent studies should extend their investigations to all industrial enterprises in the country whether or not they are listed. An extension of the study on a large sample of companies in which a majority of Tunisian companies in full growth are unlisted in stock markets, can better explain the impact of governance factors on the value and productivity of Tunisian companies. Second, this research focused on measuring productivity only for seven years, 2008 and 2014. In order to better capture the influence of governance mechanisms on the growth of value measured by productivity, we suggest that Future studies incorporate productivity data over a relatively long period.

This article offered an analytical work to contribute to knowledge of corporate governance and corporate value. It made it possible to determine, from what had already been done on the link between corporate governance and total factor productivity as a measure of the value of the business.

Several steps were necessary. In order to provide an overview of the research carried out and what could be done to improve our knowledge of the process of value creation in the company, two complementary syntheses were first carried out, one studying the impact of governance factors on the productivity of the firm, and the other analysis the relationship between total factor productivity and the various factors of corporate governance in companies conglomerate against non-conglomerate, High Tech against non-High and family against non-family.

New directions for future research to partially overcome the limitations are then proposed: adopt a synthetic vision of corporate governance (combination of theories of governance), analyze other governance mechanisms (stakeholders, shareholders, employees ...), conduct truly systemic analyzes of governance and, finally, take into account other factors of measurement of the value of the company. The possible methods for carrying out this research can come from quantitative approaches through econometric empirical models or qualitative approaches through case studies.

\section{References}

Adams, R., \& Ferreira, D. (2007). A theory of friendly boards. Journal of Finance, 62, 217-250. https://doi.org/10.1111/j.1540-6261.2007.01206.x

Aggarwal, R., Erel, I., Stulz, R., \& Williamson, R. (2009). Differences in governance practices between U.S. and foreign firms: Measurement, causes, and consequences. Review of Financial Studies, 22, 3131-3169. https://doi.org/10.1093/rfs/hhn107

Agrawal, A., \& Knoeber, C. (1996). Firm performance and mechanisms tocontrol agency problems between managers and shareholders. Journal of Financial and Quantitative Analysis, 31, 377-397. 
https://doi.org/10.2307/2331397

Aguilera, R. V. (2005). Corporate governance and director accountability: An institutional comparative perspective. British Journal of Management, 16, 39-S53. https://doi.org/10.1111/j.1467-8551.2005.00446.x

Anderson, R. C., Mansi, S. A., \& Reeb, D. M. (2004). Board characteristics, accounting report integrity, and the cost of debt. Journal of Accounting \& Economics, 37(3), 315-342. https://doi.org/10.1016/j.jacceco.2004.01.004

Arora, A., \& Gambardella, A. (1990). Complementary and external linkages: The strategies of the large firms in biotechnology. Journal of Industrial Economics, 38, 361-379. https://doi.org/10.2307/2098345

Baliga, B. R., Moyer, R. C., \& Rao, R. S. (1996). CEO duality and firm performance: what's the fuss? Strategic Management Journal, 41-53. https://doi.org/10.1002/(SICI)1097-0266(199601)17:1<41::AID-SMJ784>3.0.CO;2-\#

Barney, J. B. (1988). Returns to bidding firms in mergers and acquisitions: Reconsidering the relatedness hypothesis. Strategic Management Journal, 9, 71-78. https://doi.org/10.1002/smj.4250090708

Barth, H., La Mont, K., Lipton, L., \& Spelke, E. (2005). Abstract number and arithmetic in preschool children. Proceedings of the National Academy of Sciences, 102, 1411-1412. https://doi.org/10.1073/pnas.0505512102

Barth, M. E., Beaver, W. H., \& Landsman, W. R. (2001). The Relevance of the Value Relevance Literature for Financial Accounting Standard Setting: Another View. Journal of Accounting and Economics, 31, 77-104. https://doi.org/10.1016/S0165-4101(01)00019-2

Bhagat, S., \& Bolton, B. (2008). Corporate governance and firm performance. Journal of Corporate Finance, 14 , 257-273. https://doi.org/10.1016/j.jcorpfin.2008.03.006

Bowman, C., \& Ambrosini, V. (2000). Value Creation versus Value Capture: Towards aCoherent Definition of Value in Strategy. British Journal of Management, 15. https://doi.org/10.1111/1467-8551.00147

Brickley, J. A., Smith, Jr., \& Zimmerman, J. L. (1997). Managerial Economics and Organizational Architecture. Irwin, Chicago.

Brigham, E. F., \& Ehrhardt, M. C. (2002). Financial Management: Theory and Practice (10th ed., pp 10-11). Harcourt College Publishers.

Brown, L., \& Caylor, M. (2004). Corporate governance and firm performance. Working paper. https://doi.org/10.1920/wp.cem.2004.1804

Burkart, M., Gromb, D., \& Panunzi, F. (1997). Large shareholders monitoring and the value of the firm. Quarterly Journal of Economics, 62, 693-728. https://doi.org/10.1162/003355397555325

Cabrera-Suárez, M. K., \& Martín-Santana, J. D. (2015). Board composition and performance in Spanish non-listed family firms: The influence of type of directors and CEO duality. Bus. Res. Q., 18, 213-229. https://doi.org/10.1016/j.brq.2014.08.001

Campbell, K., \& Vera, A. M. (2010). Female board appointments and firm valuation: Short and long-term effects. Journal Management Governance, 14, 35-59. https://doi.org/10.1007/s10997-009-9092-y

Capron, L. (1999). The long-term performance of horizontal acquisitions. Strategic Management Journal, 20, 987-1018. https://doi.org/10.1002/(SICI)1097-0266(199911)20:11<987::AID-SMJ61>3.0.CO;2-B

Chan, K. C., \& Li, J. (2008). Audit Committee and Firm Value: Evidence on Outside Top Executives as Expert-Independent Directors Corporate Governance. An International Review, 16(1), 16-31. https://doi.org/10.1111/j.1467-8683.2008.00662.x

Chang, C. S., Yu, S. W., \& Hung, C. H. (2015). Firm risk and performance: The role of corporate governance. Revue. Management. Science, 9, 141-173. https://doi.org/10.1007/s11846-014-0132-x

Chang, J. J., \& Shin, H. H. (2007). Family ownership and performance in Korean conglomerates. Pacific- Basin Finance Journal, 15, 329-352. https://doi.org/10.1016/j.pacfin.2006.07.004

Charreaux, G. (1997). Le gouvernement des entreprises: Corporate Governance, théories et faits. Economica.

Chen, I. J. (2014). Financial crisis and the dynamics of corporate governance: Evidence from Taiwan's listed firms. International Review Economic and Finance, 32, 3-28. https://doi.org/10.1016/j.iref.2014.01.004

Chung, R., Firth, M., \& Kim, J. (2002). Institutional monitoring and opportunistic earnings management. Journal of Corporate Finance, 8, 29-48. https://doi.org/10.1016/S0929-1199(01)00039-6 
Claessens, S., Djankov, S., \& Lang, L. (2000). The separation of ownership and control in East Asian corporations. Journal of Financial Economics, 58, 81-112. https://doi.org/10.1016/S0304-405X(00)00067-2

Claessens, S., Djankov, S., \& Lang, L. H. P. (2006). The benefits and costs of group affiliation: Evidence from East Asia. Emerging Markets Review, 7(1), 1-26. https://doi.org/10.1016/j.ememar.2005.08.001

De Jong, A., Dejong, D. V., Mertens, G., \& Wasley, C. E. (2005). The Role of Self-Regulation in Corporate Governance: Evidence and Implications from The Netherlands. Journal of Corporate Finance, 11, 473-503. https://doi.org/10.1016/j.jcorpfin.2004.01.002

Del Monte, A., \& Papagni, E. (2003). R\&D and the growth of firms: an empirical analysis of a panel of Italian firms. Research Policy, 32, 1003-1014. https://doi.org/10.1016/S0048-7333(02)00107-5

Deloof, M. (2003). Does working capital management affect profitability of Belgian firms. Journal of Business Finance and Accounting, 30, 573-588. https://doi.org/10.1111/1468-5957.00008

Demestez, H. (1983). The Structure of Ownership and the Theory of the Firm. Journal of Law and Economics, 26, 375-390. https://doi.org/10.1086/467041

Demsetz, H., \& Villalonga, B. (2001). Ownership structure and corporate performance. Journal of Corporate Finance, 7, 209-233. https://doi.org/10.1016/S0929-1199(01)00020-7

Fich, E. M., \& Shivdasani, A. (2006). Are Busy Boards Effective Monitors? Journal of Finance, 61, 689-724. https://doi.org/10.1111/j.1540-6261.2006.00852.x

Filatotchev, I., Lien, Y., \& Piesse, J. (2005). Corporate governance and performance in publicly listed, family-controlled firms: Evidence from Taiwan. Asia Pacific Journal of Management, 22, 257-283. https://doi.org/10.1007/s10490-005-3569-2

Finegold, D., Benson, G. S., \& Hecht, D. (2007). Corporate Boards and Company Performance: Review of Research in Light of Recent Reforms. CorporateGovernance: An International Review, 15, 865-878. https://doi.org/10.1111/j.1467-8683.2007.00602.x

Franks, J., Mayer, C., \& Renneboog, L. (2001). Who disciplines management in poorly performing companies? Journal of Financial Intermediation, 10, 209-48. https://doi.org/10.1006/jfin.2001.0317

Friedman, M. (1971). The Social Responsibility of Business is to Increase its profits. The New York Times Magazine, September 13.

García-Ramos, R., \& García-Olalla, M. (2014). Board independence and firm performance in Southern Europe: A contextual and contingency approach. Journal Management and Organisationnel, 20(3), 313-332. https://doi.org/10.1017/jmo.2014.23

Gaughan, P. A. (2002). Mergers, acquisitions and corporate restructurings (3rd ed.). John Wiley et Sons.

Gillan, S., \& Starks, L. (2000). Corporate governance proposals and shareholder activism: The role of institutional investors. Journal of Financial Economics, 57, 275-305. https://doi.org/10.1016/S0304-405X(00)00058-1

Gilsing, V., Nooteboom, B., Vanhaverbeke, W., Duysters, G., \& Van Den Oord, A. (2008). Network embeddedness and the exploration of novel technologies: Technological distance, between ness centrality and density. Research Policy, 37, 1717-1731. https://doi.org/10.1016/j.respol.2008.08.010

Ginglinger, E., \& L'her, J. F. (2006). Ownership structure and open market stock repurchases in France. European Journal of Finance, 12, 77-94. https://doi.org/10.1080/13518470500039543

González, V. M. (2013). Leverage and corporate performance: International evidence. International Review of Economics \& Finance, 25, 169-184. https://doi.org/10.1016/j.iref.2012.07.005

Good Governance Code. (2015). Good Governance Code of Listed Companies. Retrieved from http://www.cnmv.es

Hillman, A. J., Shropshire, C., Certo, S. T., Dalton, D. R., \& Dalton, C. M. (2011). What I like about you? A multilevel study of shareholder discontent with director monitoring. Organ. Sci., 22(3), 675-687. https://doi.org/10.1287/orsc.1100.0542

Holan, P., Martin, D., \& Sanz, L. (2006). Protected by the family? How closely held family firms protect minority shareholders. Journal of Business Research, 59, 356-359. https://doi.org/10.1016/j.jbusres.2005.09.009

Hossain, M., Prevost, A. K., \& Rao, R. P. (2001). Corporate Governance in New Zealand: The Effect of the 1993 
companies act on the relation between board composition and firm performance. Pacific- Basin Finance Journal, 9, 119-145. https://doi.org/10.1016/S0927-538X(01)00003-8

Ikenberry, D., Lakonishok, J., \& Vermaelen, T. (1995). Market under reaction to open market share repurchases. Journal of Financial Economics, 39, 181-208. https://doi.org/10.1016/0304-405X(95)00826-Z

Institute of Internal Auditors (IIA). (1999). Definition of internal auditing: IIA professional practices framework. Altamonte Springs, FL.

Jensen, M. C. (2001). Value Maximization, Stakeholder theory, and the Corporate Objective Function. Working paper Social Science Research Network. https://doi.org/10.1111/j.1745-6622.2001.tb00434.x

Jensen, M., \& Meckling, W. (1976). Theory of the firm: Managerial behaviour, agency costs and ownership structure. Journal of Financial Economics, 3, 305-360. https://doi.org/10.1016/0304-405X(76)90026-X

Jordan, C. E., Clark, S. J., \& Smith, W. R. (2007). Should earnings per share (EPS) be taught as a means of comparing intercompany performance? Journal of Education for Business, 82(6), 343-348. https://doi.org/10.3200/JOEB.82.6.343-348

Kaymak, T., \& Bektas, E. (2008). East meets west? Board characteristics in an emergingmarket: Evidence from Turkish banks. Corporate Governance, 16(6), 550-561. https://doi.org/10.1111/j.1467-8683.2008.00713.x

Khurana, I. K., \& Kim, M. (2003). Relative value relevance of historical cost vs. fair value: Evidence from bank holding companies. Journal of Accounting and Public Policy, 22(1), 19-42. https://doi.org/10.1016/S0278-4254(02)00084-4

Klein, A. (2002). Audit committee, board of director characteristics, and earnings management. Journal of Accounting and Economics, 33(3), 375-400. https://doi.org/10.1016/S0165-4101(02)00059-9

Knight, J. A. (1998). Value Based Management: Developing a Systematic Approach to Creating Shareholder Value. New York: Mc Graw-Hill.

Mcdonald, M. L., Khanna, P., \& Westphal, J. D. (2008). Getting them to think outside the circle: Corporate governance, CEOs' external advice networks, and firm performance. Academy of Management Journal, 51, 453-475. https://doi.org/10.5465/AMJ.2008.32625969

Mínguez-Vera, A., \& López-Martínez, R. (2010). Female directors and SMES: An empirical analysis. Journal Global Strategic Management, 8, 30-46. https://doi.org/10.20460/JGSM.2010415823

Nicholson, G. J., \& Kiel, G. C.(2007). Can directors impact performance? A case-based test of three theories of corporate governance. Corporate Governance International Review, 15(4), 585-608. https://doi.org/10.1111/j.1467-8683.2007.00590.x

Pucheta-Martínez, M. C. (2015). El papel del Consejo de Administración en la creación de valor en la empresa. $\begin{array}{lllll}\text { Revista de Contabilidad/Spanish Accounting Review, } & \text { 18(2), }\end{array}$ https://doi.org/10.1016/j.rcsar.2014.05.004

Stewart. (2009). Review Article: Bainbridge's The New Corporate Governance. Working Paper Series, 5. https://doi.org/10.2139/ssrn.1497622

Unified Good Governance Code. (2006). Unified Good Governance Code of Listed Companies. Retrieved from http://www.cnmv.es

Vithessonthi, C., \& Tongurai, J. (2015). The effect of leverage on performance: Domestically oriented versus internationally-oriented firms. Research in International Business and Finance, 34, 265-280. https://doi.org/10.1016/j.ribaf.2015.02.016

Vivel, M., Otero, L., Fernández, S., \& Durán, P. (2015). Is value creation consistent with currency hedging? European Journal Finance, 21(10-11), 912-945. https://doi.org/10.1080/1351847X.2013.773262

Yang, T., \& Zhao, S. (2014). CEO duality and firm performance: Evidence from an exogenous shock to the competitive environment. Journal of Banking \& Finance, 49, 534-552. https://doi.org/10.1016/j.jbankfin.2014.04.008

\section{Copyrights}

Copyright for this article is retained by the author(s), with first publication rights granted to the journal.

This is an open-access article distributed under the terms and conditions of the Creative Commons Attribution license (http://creativecommons.org/licenses/by/4.0/). 